\title{
ARTICLES
}

Submitted 10.10.2016. Approved 09.12.2017

Evaluated through a double-blind review process. Scientific Editor: Carlos Jesús Fernández Rodríguez

Original version

DOI: http://dx.doi.org/10.1590/So034-759020180404

\section{THE MEDIATING ROLE OF VIRTUOUSNESS IN HUMAN RESOURCE MANAGEMENT AND JOB OUTCOMES}

\author{
Papel mediador da virtuosidade na gestão de recursos humanos e resultados \\ do trabalho \\ El rol mediador de la virtuosidad en la gestión de recursos humanos y los \\ resultados del trabajo
}

\begin{abstract}
In this study, we explore the role of organizational virtuousness (OV) as a mechanism through which human resource management practices (HRMPs) affect employee outcomes. We propose that HRMPs lead to higher levels of organizational citizenship behaviors and affective commitment by stimulating OV. Using a sample of 525 workers, from 22 stores of a retailing company, we found evidence that HRMPs predict OV, thereby predicting members' citizenship behaviors and affective commitment. By suggesting this new mediator, this study contributes to a better understanding of the causal chain linking HRMPs and performance.
\end{abstract}

KEYWORDS | Human resource management, organizational virtuousness, organizational citizenship behavior, affective commitment, mediation.

\section{RESUMO}

Nesta pesquisa, exploramos o papel da virtuosidade organizacional como um mecanismo por meio do qual as práticas de gestão de recursos humanos ( $P G R H$ ) influenciam os resultados no nível dos colaboradores. Propomos que as PGRH conduzem a níveis mais elevados de comportamentos de cidadania organizacional e comprometimento afetivo, estimulando a virtuosidade organizacional (VO). Numa amostra de 525 colaboradores, de 22 lojas de uma empresa de retalho, encontramos evidência de que as PGRH predizem a VO e que esta prediz os comportamentos de cidadania e o comprometimento afetivo dos membros da organização. Ao propor esse novo mediador, este estudo contribui para uma melhor compreensão da cadeia causal que liga as PGRH e o desempenho.

PALAVRAS-CHAVE / Gestão de recursos humanos, virtuosidade organizacional, comportamento de cidadania organizacional, comprometimento afetivo, mediação.

leonor.pires@estsetubal.ips.pt

ORCID: 0000-0003-4314-5755

\section{FRANCISCO NUNES 2}

francisco.nunes@iscte.pt

ORCID: 0000-0001-5848-6451

${ }^{1}$ Escola Superior de Tecnologia do Instituto Politécnico de Setúbal, Estefanilha, Setubal, Portugal

2Instituto Superior de Ciências do Trabalho e da Empresa, Business Research Unit, Lisboa, Portugal

\section{RESUMEN}

En esta investigación exploramos la función que tiene la virtuosidad organizacional como un mecanismo a través del cual las prácticas de gestión de recursos humanos (PGRH) influencian los resultados del trabajo. Así, nuestro objetivo es plantear que las PGRH aumentan el nivel de comportamientos de ciudadanía y de compromiso afectivo cuando se incentiva la virtuosidad organizacional. En una muestra de 525 trabajadores pertenecientes a 22 tiendas de una empresa minorista encontramos pruebas de que las PGRH predicen la virtuosidad organizacional y esta, a su vez, predice los comportamientos de ciudadanía y el compromiso afectivo de los miembros de la organización. Al proponer este nuevo mediador, este estudio contribuye a una mejor comprensión de la cadena causal que conecta las PGRH y el desempeño

PALABRAS CLAVE / Gestión de recursos humanos, virtuosidad organizacional, comportamientos de ciudadanía, compromiso afectivo, mediación. 


\section{INTRODUCTION}

The study of the relationship between human resource management practices (HRMPs) and performance has received considerable attention, and empirical research yields abundant confirmatory evidence (Combs, Liu, Hall, \& Ketchen, 2006; Jiang, Lepak, Hu, \& Baer, 2012). This relationship is usually seen as a chain starting with HRMPs and finishing with operational and financial organizational outcomes (Becker, Huselid, Pickus, \& Spratt, 1997; Dyer \& Reeves, 1995). In the middle, this causal chain comprises employee-level attitudes and behaviors (Kehoe \& Wright, 2013), such as job satisfaction and commitment (Takeuchi, Chen, \& Lepak, 2009) or service-oriented citizenship behaviors and turnover (Sun, Aryee, \& Law, 2007). HRMPs affect those outcomes, thereby leading to enhanced organizational performance. However, studies on mechanisms linking HRMPs and organizational performance, such as the abovementioned proximal employee outcomes, are underdeveloped, demanding more attention on understanding the relationship (Takeuchi, Chen, \& Lepack, 2009; Kehoe \& Wright, 2013).

Current explanations of the relationship between HRMPs and attitudinal and behavioral proximal outcomes are mainly based on the social exchange theory, regardless of these explanations being explicit (Gong, Law, Chang, \& Xin, 2009; Sun et al., 2007; Takeuchi, Lepak, Wang, \& Takeuchi, 2007) or implied in intervening variables such as justice (Heffernan \& Dudon, 2012) or organizational support (Kuvaas, 2008). Within this perspective, HRMPs are part of an exchange relationship that organizations establish with employees. If employees' perceptions of their organization or job are positive, they reciprocate with greater commitment, satisfaction, loyalty, and productivity. However, empirical research reports inconsistent relationships between HRMPs and employee attitudes and behaviors. For instance, while Ahmad and Shroeder (2003) found positive relationships between HRMPs and organizational commitment, Bal, Kooij, and De Jong (2013) reported much less intense or insignificant relationships between different HRMPs and affective commitment. In our view, an intervening variable might explain this inconsistency. By studying the relationship between HRMPs and affective commitment at the individual level within a social exchange framework, Meyer and Smith (2000) found that perceived organizational support and procedural justice mediate these relationships, leading the authors to conclude that HRMPs can be valuable in establishing and maintaining employees' commitment; however, their effect was not direct or unconditional. We concur with Meyer and Smith (2000) regarding the existence of an intervening variable in the relationship between HRMPs and employee attitudes and behaviors; however, instead of relying on the social exchange theory as an explanation, we suggest that organizational virtuousness (OV) offers a viable, alternative explanation.

$\mathrm{OV}$ is an organizational level attribute and refers to “individuals' actions, collective activities, cultural attributes or processes that enable dissemination and perpetuation of virtuousness in an organization" (Cameron, Bright, \& Caza, 2004, p. 768). Virtuousness is associated with Aristotelian goods of first intent meaning "that which is good in itself and is to be chosen for its own sake" as opposed to goods of second intent which are "good for the sake of obtaining something else" (Cameron et al., 2004, p. 769). As part of the positive scholarship, OV is based on a set of assumptions about human and organizational nature encompassing honesty, compassion, loyalty, respect, and forgiveness, a phenomenon studied through theories on extraordinary performance, positive deviance, and the positive spiral of flourishing. This perspective contrasts with the more commonly accepted view of social relationships based on conflict, retribution, and contract breaking, studied with theories of reciprocity and justice, overcoming resistance, or competition (Cameron, Dutton, \& Quinn, 2003).

In general, virtuousness involves a positive impact on human beings, moral goodness, and the prevalence of societal benefit rather than individual interests (Bright, Cameron \& Caza, 2006). Instead of reciprocity as the main motivator for employees' pro-organizational attitudes and behaviors, OV emphasizes the motivational influence of doing the right thing for the sake of people (Cameron \& Winn, 2012). Experiencing OV has a strong prescriptive effect on individuals, leading them to act consistently and as role models for other individuals, thus generating a collective positive pattern of behaviors and emotions that creates a self-reinforcing virtuous spiral. Thus, employees' positive attitudes and behaviors are constituents of $\mathrm{OV}$ and not the consequences of a favorable exchange relationship between employees and organizations.

Organizations can create practices to instill positive interpersonal relationships, meaningful work, enhanced learning, and personal development of employees, whose impact on humans enables virtuousness at the organizational level (Cameron \& Win, 2012). Thus, we suggest that HRMPs such as training, job design, or careers, if perceived as appropriate to advance individuals and organizations, i.e., viewed as goods of first intent and inherently worthy by employees, can foster a shared perception of OV. Embedded within a virtuous context, employees will display organizational citizenship behaviors and affective commitment-integral parts of the virtuous character of the organization.

Thus, our research aims to contribute to the debate regarding the chain of causal linkages between HRMPs and 
organizational outcomes by suggesting OV as an explanatory mechanism. We predict that HRMPs leads to higher perceptions of OV, which mediates the relationships between HRMPs and organizational citizenship behaviors and between HRMPs and affective commitment. Data obtained from a sample of 525 workers from 22 stores of a retailing company support our predictions.

This study is organized as follows. The next section presents a theoretical background on OV's research domains and its foreseeable relationship with HRMPs, affective commitment, and organizational citizenship behaviors. The third section describes methods - data collection, sample, measures and statistical procedures. The fourth section reports data analysis and results, which are discussed later in the fifth section. The last section contains conclusions and limitations, implications for practice, and suggestions for future research.

\section{THEORETICAL FRAMEWORK}

\section{Organizational virtuousness}

With roots in ancient Greek philosophical traditions (Bright, Winn, \& Kanov, 2014), but having its own distinctive features (Sison \& Ferrero, 2015), the concept of OV emerges from a stream of positive studies on organizations (Cameron \& Winn, 2012). According to early approaches, virtuousness has three major properties (Bright et al., 2006): human impact, moral goodness, and unconditional societal benefit. Here, virtuousness describes desirable or right actions in a society, entails a positive effect on humanity, and transcends self-individual interests to benefit society. More recently, at the individual level, Cameron and Winn (2012) expanded this view by adding the so-called eudaemonic and inherent value assumptions. Both assumptions take a strong position regarding what fundamentally motivates human beings. Briefly, humans are seen as entities characterized by a proclivity to seek what is good and inherently worthy, the eudaemonic and inherent value assumptions, respectively. At the collective level, Cameron and Winn (2012) suggest the amplifying effect as another property of virtuousness, wherein the experience of virtuousness motivates people to feel empowered to act in a consistent way and create a context that inspires others to act accordingly, generating positive emotions and increased individual performance, thereby reinforcing $O V$. In line with this attribute of virtuousness at the collective level, research has adopted a more pragmatic approach by studying OV's impacts on performance at both organizational and individual levels (Cameron, Mora, Leutscher, \& Calarco, 2011).

OV is described as a multidimensional construct integrating five dimensions: optimism, trust, compassion, integrity, and forgiveness (Cameron et al., 2004). Optimism is a sense of purpose implying doing good besides doing a good job and also the belief in being successful despite challenges. Trust refers to emphasis on establishing mutually trustful relationships among organizational members and involves treating people with courtesy, consideration, and respect. Compassion includes the recurrent exhibition of acts of kindness, care and concern for others, and the use of stories of concern and compassion as reinforcing mechanisms. Integrity comprises honesty, loyalty, honor, and high standards of reliability. Forgiveness reflects being compassionate and able to forgive mistakes once recognized, corrected, and used as learning opportunities. This set of organizational level attributes creates a context that stimulates consistent actions among members who will experience positive emotions, increased willingness to help customers, become more attentive and respectful toward co-workers, and be more likely to search for innovation to benefit the organization. Thus, the process by which OV influences employees' attitudes and behaviors is the same as in other organizational level constructs, such as culture and climate. The inherent value of OV's content differentiates it from other concepts. This argument echoes with the notions of stewardship (Hernandez, 2008), self-determination (Deci \& Ryan, 2008), or job crafting (Berg, Dutton, \& Wrzesniewski, 2013), because they emphasize the importance of altruistic motives in contrast to individual agency, the motivational effects of intrinsic or integrated regulation compared to extrinsic-based motivation, and the energizing effect of extracting meaning from the job instead of merely performing narrow tasks.

Organizations can create practices to perpetuate flourishing interpersonal relationships, meaningful work, employees' enhanced learning, and personal development, whose impact on humans enables virtuousness at the organizational level and embedded pro-organizational attitudes and behaviors. Thus, we argue that HRMPs such as training, job design, enhancing participation, and career-focused practices are perceived as goods of first intent and inherently worthy, and foster a shared perception of OV that induces employees' emotions and behaviors mirroring, at the individual level, the virtuous character of the organization, thus reinforcing this characteristic.

\section{The relationship between HRMPs and OV}

OV is still a relatively unexplored concept in the field of HRMPs, although some authors include a moral dimension in their explanations of the effect of HRMPs and outcomes, which is akin to OV (Park \& Peterson, 2003), or argue that virtue, a moral 
character developed through learning the fundamental principles of organizations, becomes a major generator of the happiness that organizations should create among their employees (Gavin \& Mason, 2004). Similarly, Bernacchio and Couch (2015), using the case of Mondragon Cooperative Corporation, show how organizations can use participatory management practices to institutionalize a concern for the common good.

Research on HRMP's impact on ethical climates (Weaver \& Treviño, 2001) suggests that organizations can improve their climate's ethical nature by focusing on two types of HRMPs: valueoriented, when practices stimulate a generalized commitment to act ethically in a self-management way, and compliance-oriented, when practices impose rules and standards of ethical conduct. Especially value-oriented programs, but also compliance-oriented ones, are designed to influence organizational members to move away from egoistic interests towards other concerns, such as the well-being of the organization, co-workers, and other stakeholders. More recently, Guerci, Radaelli, Siletti, Cirella, and Shani (2015) expanded this argument by stating that HRMPs themselves can embody both value-oriented and compliance messages, creating less egoistic ethical climates. Empirical evidence supports the authors' proposition. We take this further by asserting that HRMPs are part of organizational processes that influence perceptions of OV, although they are not explicitly designed to include a virtuous character or another ethical meaning. Because management can be seen as a humanistic endeavor (Arnaud \& Wasieleski, 2014) when "its outlook emphasizes common human needs and is oriented to the development of human virtue" (Melé, 2003, p. 77), HRMPs are important sources of OV.

Based on a humanistic management argument composed of a set of practices created to foster human dignity (Spitzeck, 2011), we can argue that a properly designed workplace should allow members to exercise their freedom, create developmental challenges for individuals' potential, and send signals of recognition and acceptance so that members are not just considered as a means for organizational ends (Arnaud \& Wasieleski, 2014). HRMPs are thus a privileged vehicle for employees to infer the moral goodness, human impact, and generalized benefit provided by organizations. Because HRMPs can signal the importance of customers and contribute to creating a service climate (Yagil, 2014), when signaling dignity and respect, support, caring, meaning, forgiveness, and inspiration (Cameron et al. 2011), they can generate virtuousness. Although some specific HRMPs such as selection or training could affect specific dimensions of OV such as integrity or forgiveness, we suggest a generalized influence. In the strategic human resource management literature, there is consensus regarding the synergistic effect of bundles of HRMPs or the Human Resource Managment system characterized by several interdependent and mutual reinforcing practices, or the so-called horizontal alignment (Gratton \& Truss, 2003) that creates positive effects on organizational performance (Guest, 1997; Becker et al., 1997). Accordingly, we posit the following hypothesis:

H1: HRMPs are positively related to OV.

\section{OV, organizational citizenship behaviors, and affective commitment}

We suggest that OV induces pro-organizational attitudes and behaviors because positive outcomes are a part of OV based on the literature on organizational climate (Ehrhart, Schneider, \& Macey, 2014) and culture (Chatman \& O'Reilly, 2016). Although these are distinct constructs with a different history and rooted in non-coincident intellectual traditions (Schneider, GonzálezRomá, Ostrof, \& West, 2017), they both refer to organizational level attributes that allow employees to give meaning to their experiences in organizations and become aware of which behaviors are rewarded, supported, and expected (in the case of climate), and offer a system of shared values and assumptions that explains why organizations do what they do (in the case of culture). In both the cases, an organizational level characteristic, among other things, prescribes the appropriate way of feeling, thinking, and acting for its members (Schein, 2010). OV describes an organization characterized by optimism, trust, compassion, integrity, and forgiveness, a set of characteristics that will signal pro-organizational behaviors as the appropriate way to act in organizations and an affective connection between individuals and their organizations as the appropriate way to feel.

More specifically, the OV theory suggests that pro-social behavior is a consequence of virtuousness at the individual level (Cameron et al., 2004; Staw \& Barsade, 1993). Employees with positive experiences at work and who are subject to various forms of virtuosity, are more likely to exhibit client-centric behaviors, help colleagues, protect the organization spontaneously, and make constructive suggestions. This proposition has already received empirical support, given that research shows a positive relationship between OV dimensions and organizational citizenship behaviors (Ribeiro \& Rego, 2009; Rego, Ribeiro, \& Pina e Cunha, 2010). Accordingly, our hypothesis is as follows:

$\mathrm{H} 2$ : OV is positively related to organizational citizenship behaviors.

Current explanations for variations in organizational commitment highlight the role of positive experiences, especially those arising from positive jobs and work experiences (Meyer \& 
Allen, 1991). However, when HRMPs are invoked to explain affective commitment, is how practices communicate organizational support, fair treatment, and interest in building employees' selfworth and importance that are con sidered important and not the practices themselves (McElroy, 2001), pointing to an indirect relationship between HRMPs and commitment. Again, we suggest that OV can appropriately fulfill this mediating role. Employees that perceive organizations as promoting OV learn by personal experience and observation to live in a context requiring a positive attachment from its members, herein conceptualized as affective commitment. Thus, we hypothesize the following:

$\mathrm{H}_{3}$ : OV is positively related to affective commitment

Although our argument, expressed in hypotheses two and three, points to the full mediation of the relationship between HRMPs and citizenship behavior and affective commitment by OV (Figure 1), the literature offers arguments suggesting the existence of a direct relationship between HRMPs and these two outcomes. Thus, OV would partially mediate the above relationships. Testing that possibility is relevant because it will enable a better understanding of the nature of linkage between HRMPs and individual-level outcomes.

\section{Figure 1. Theoretical model and hypotheses}

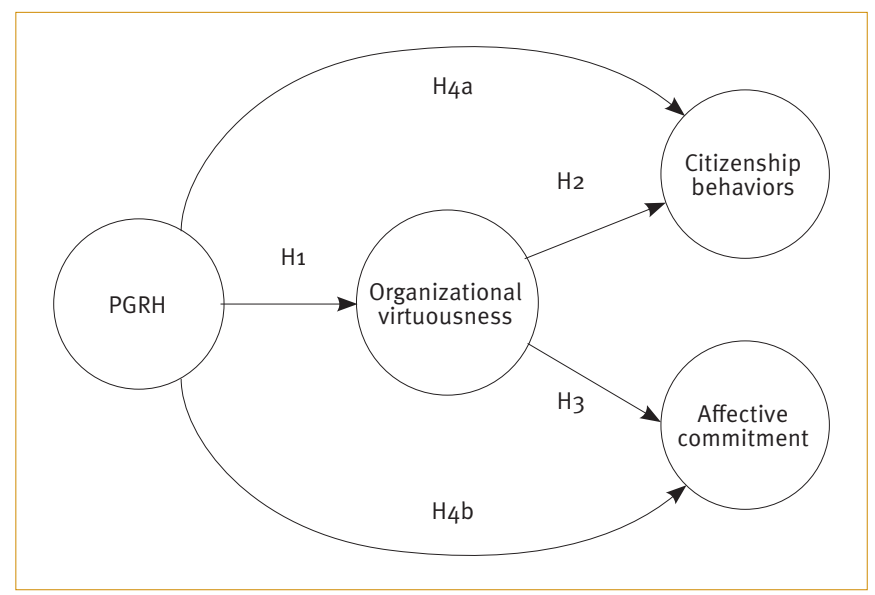

Considering organizational citizenship behaviors, the literature also supports a direct relationship with HRMPs (Morrison, 1996; Sun et al., 2007). By managing recruitment, selection, and socialization of new employees, evaluating their performance, rewarding them, and creating internal regulations and formal job descriptions, organizations can influence citizenship behaviors. Newman, Miao, Hofman, and Zhou (2016) showed that both employee- and facilitation-oriented HRM models have a positive effect on organizational citizenship behaviors. Similarly, the direct relationship between HRMPs and commitment has also been studied. Based on the social exchange theory, Tsui, Pearce, Porter, and Tripoli (1997) found a significant and positive relationship between HRMPs, representing mutual investment and overinvestment, and affective commitment. Similarly, Whitener (2001) found an influence of HRMPs upon employees' commitment, and more recent research points in the same direction (Bal, Kooji, \& De Jong, 2013; Lamba \& Choudary, 2013; Fabi, Lecoursiére, \& Raymond, 2015). Moreover, the study by Kehoe and Wright (2013) found that employee's perceptions of HRMPs were related to both affective commitment and organizational citizenship behaviors. Consequently, the following hypothesis is proposed:

$\mathrm{H}_{4}$ : OV will partially mediate the relationship between HRMPS and a) citizenship behaviors and b) affective commitment.

\section{METHOD}

We tested the model and hypotheses using a sample of employees from 22 stores of a food retailing company. Data collection from individuals who work in the same company's stores is a common sampling strategy (Koys, 2001; Bell \& Menguc, 2002; Wright, Gardner, \& Moynihan, 2003; Schneider, Ehrhart, Mayer, Saltz, \& Niles-Jolly, 2005), which is useful in finding the variance in HRMPs within organizations and studying employee perceptions and reactions to these practices, allowing researchers to control for unidentifiable sources of variance that are common in research wherein data is collected from different companies and sectors of activity and thus providing a clearer view of the HRMPs impact on relevant outcomes (Wright et al., 2003; Lepak, Liao, Chung, \& Harden, 2006). The information provided by the Human Resources department led us to consider that, while there is uniformity in HRMPs within the company, the stores have some autonomy in their application, which allows some variation between stores. We calculated the intra-class correlation for HRMPs revealing that $18 \%$ variance is due to differences between stores.

\section{Sample}

Data were collected from each company store, resulting in a sample of 525 employees, which comprised $50.9 \%$ male respondents with a mean age of 37.8 years (standard deviation $=8.9$ ). The predominant level of schooling was secondary education (67.4\%). On an average, the respondents had 10.6 (s.d. 7.9) years tenure and 8.0 (s.d. 7.0) years in the present job. The majority of respondents $(72.8 \%)$ had operational functions, comprising customer service, and $12 \%$ had managerial jobs. Most respondents (89.3\%) had direct contact with customers, and $89 \%$ were permanent employees. 


\section{Measures}

All the survey items were answered on five-point rating scales, ranging from strongly disagree (1) to strongly agree (5).

\section{Service-oriented organizational citizenship behaviors}

We used the scale developed by Bettencourt, Gwinner, and Meuter (2001) for measuring organizational citizenship behaviors as a context-sensitive measure applied to services, because it fits the nature of the retailing context wherein we tested our model. This measure encompasses three dimensions: loyalty (e.g. item: "Says good things about the store to others"), service delivery (e.g. item: "Follows customer service guidelines with extreme care"), and participation (e.g. item: "Makes constructive suggestions for service improvement"). We performed confirmatory factor analysis (CFA) to assess the data fit of a three-dimensional scale. An overall second order factor revealed acceptable values of fit $\left(x^{2}(95)=266.84 ; p=0.000, x^{2} / d f=2.81 ; C F I=0.96 ; R M S E A=\right.$ $0.06 ; \mathrm{GFI}=0.94 ; \mathrm{TLI}=0.95 ; \mathrm{SRMR}=0.04)$. Additionally, all subscales showed good reliability with Cronbach's alpha above 0.80 . We used composites of each subscale as indicators of the latent variable of service-oriented organizational citizenship behaviors (Chuang \& Liao, 2010; Zacharatos, Barlin, \& Iverson, 2005).

\section{Affective commitment}

We measured affective commitment with a Portuguese adaptation of the six-item scale created by Meyer and Allen (1997), developed by Nascimento, Lopes, and Salgueiro (2008), a e.g. item being: "I feel a strong sense of belonging to this store." Based on the CFA results, we accepted four items after eliminating items with loads below 0.40 . The fit for this scale was acceptable $\left(x^{2}(2)\right.$ $=3.44 ; \mathrm{P}=0.17 ; \mathrm{x}^{2} / \mathrm{df}=1.72 ; \mathrm{CFI}=0.99 ; \mathrm{RMSEA}=0.03 ; \mathrm{GFI}=$ 0.96; TLI $=0.99 ;$ SRMR $=0.01$ ), as was its reliability (Cronbach's Alpha $=0.79$ ).

\section{OV}

Perceptions of OV were measured using the 15 -item scale proposed by Cameron et al. (2004). We conducted CFA to test the existence of the five components proposed: optimism (e.g. item: "We are optimistic that we will succeed, even when faced with major challenges"), trust (e.g. item: "Employees trust one another in this store"), compassion (e.g. item: "Acts of compassion are common here"), integrity (e.g. item: "This organization demonstrates the highest levels of integrity"), and forgiveness (e.g. item: "This is a forgiving, compassionate store in which to work"). The overall second-order model yielded an acceptable fit $\left(x^{2}(78)=184.51\right.$; $P$ $=0.00 ; x^{2} / d f=2.36 ; \mathrm{CFI}=0.98 ; \mathrm{RMSEA}=0.05 ; \mathrm{GFI}=0.96 ; \mathrm{TLI}=$ $0.97 ;$ SRMR $=0.03)$. All sub-scales showed good reliability, with Cronbach's alpha ranging from 0.74 to 0.85 . We used composites of each subscale as indicators of OV.

\section{Human Resources Management Practices}

Perceptions of HRMPs were measured based on the scale developed by Sun et al. (2007), seeking to cover a set of practices describing a high-performance work system. The original scale included items for the following practices: training (e.g. item: "Extensive training programs are provided to employees"), recruitment and selection (e.g. item: "Great effort is taken to select the right person"), participation (e.g. item: "Employees in this job are often asked by their supervisor to participate in decisions"), compensation (e.g. item: "There is a close tie or matching of pay to individual/group performance”), mobility (e.g. item: "Employees have clear career paths in this store"), job security (e.g. item: "Job security is almost guaranteed”), job description (e.g. item: “This job has an up-to-date description"), and performance appraisal (e.g. item: "Performance appraisals are based on objective quantifiable results").

Based on exploratory factor analysis, comparing our solution with the original one, two changes were introduced: a) items pertaining to participation and performance assessment saturate the same factor; to acknowledge this association, we labeled this dimension "involvement and performance assessment"; b) items measuring job security and compensation also saturated the same factor; hence, we labeled this dimension as "employment conditions." We submitted all remaining items to CFA and identified a second-order factor model with six dimensions with a good fit $\left(x^{2}(176)=408.35 ;\right.$ P P $0.001 ; x^{2} / d f=2.32 ; C F I=0.95$, RMSEA $=0.05 ; \mathrm{GFI}=0.93 ; \mathrm{TLI}=0.94 ; \mathrm{SRMR}=0.04)$. The final retained dimensions were involvement and performance, recruitment and selection, training, employment conditions, internal mobility, and job description. These dimensions reflected the perceptions of HRMPs as implemented in stores, and hence, were retained. All subscales showed good internal consistency, with Cronbach's alpha ranging between 0.74 and 0.87 .

\section{Control variables}

Although research on the effects of demographic or professional variables on organizational citizenship behaviors and affective commitment tend to reveal no or weak relationships (Mathieu \& Zajack, 1990; Podsakoff, Mackenzie, Paine, \& Bacharach, 2000), we included several variables deemed relevant to the analysis: 
age, gender, job tenure, and education in correlation analyses. The results confirm the already established tendency of low or nonexistent relationships.

\section{Analyses}

Because all variables were collected from the same source, the data are vulnerable to common method variance. Hence, we used Harman's one test factor (1967), which resulted in 13 factors, the first explaining only $28 \%$ of the total variance. Second, following Podsakoff, Mackenzie, Lee, and Podsakoff (2003), we included a method factor in the measurement model, explaining $12 \%$ of the variance. Finally, we tested a measurement model including predictor, mediator, and criterion variables, a procedure that yields acceptable results $\left(x^{2}(123)=320.08 ; p<0.001 ; x^{2} / d f=\right.$ 2.6; $\mathrm{RMSEA}=0.05 ; \mathrm{TLI}=0.94 ; \mathrm{SRMR}=0.06)$. Thus, although common method bias cannot be discarded completely, common method variance should not affect the validity of the findings. The hypotheses were tested using structural equation modeling.

\section{RESULTS}

Descriptive statistics, intercorrelations, and reliabilities for all variables are reported in Table 1 . For control variables and considering only significant relationships, we found that older employees have more positive perceptions of HRMPs $(r=0.13$; $p<0.01)$, higher levels of organizational citizenship behaviors $(r=0.21 ; p<0.01)$ and affective commitment $(r=0.14$; $p<0.01)$; the only significant and positive relationship of gender is with affective commitment ( $r=0.14$; $p<0.05)$, with higher scores for males. Positive correlations were found between the predictor and criteria variables, according to the hypothesized relationships. Thus, HRMPs perceptions showed a positive correlation with OV perceptions ( $r=0.73$; $p<0.001$ ). HRMPs was correlated significantly with service-oriented organizational citizenship behaviors $(r=0.46$; $p<0.001)$ and with affective commitment $(r$ $=0.38$; $p$ (0.001). OV showed positive correlations with serviceoriented organizational citizenship behaviors $(r=0.54$; $p<0,001)$ and with affective commitment $(r=0.43$; p<0.001), as predicted.

The proposed research model showed a good fit for the data $\left(x^{2}(132)=331.90 ; p<0.001 ; x^{2} / d f=2.51 ; \operatorname{RMSEA}=0.05\right.$; SRMR $=0.06)$. The data supported hypothesis 1 of positive association between HRMPs and OV (Beta =0.73; p<0.001; $\mathrm{R}^{2}=$ 0.54). Hypothesis 2 proposed a positive association between OV and organizational citizenship behaviors and is also supported (Beta $\left.=0.51 ; p<0,001 ; R^{2}=0.20\right)$. Hypothesis 3 suggested a positive relationship between $\mathrm{OV}$ and affective commitment and was supported $\left(B e t a=0.45 ; p<0.001, R^{2}=0.26\right)$. Figure 2 depicts these results.

To test hypothesis four, we added two additional paths to the model presented in Figure 2, linking HRMPs directly to organizational citizenship behaviors and affective commitment, thus testing the partial mediation role of $\mathrm{OV}$. Fit indices of the model with direct paths achieved acceptable thresholds $\left(\mathrm{x}^{2}(130)=327.80 ; \mathrm{p}<0.001 ; \mathrm{x}^{2} / \mathrm{df}=\right.$ 2.52; RMSEA $=0.05 ;$ SRMR $=0.06$ ), and the test of the difference between the fit of both did not yield statistically different results $(p=0.13)$. Direct and indirect effects of HRMPs on organizational citizenship behaviors and affective commitment were calculated according to Cheung and Lau's (2008) procedure for determining parameters and confidence intervals based on resampling from the original dataset (in this study, 2000 bootstrap samples). Concerning the relationship between HRMPs and organizational citizenship behaviors, the direct effect estimate was 0.11 ( $p<0.14$ ), and the standardized indirect effect, mediated by OV, was 0.24 ( $p<0.02 ; 95 \%$ $\mathrm{Cl} 0.11$ to 0.31 ). Regarding affective commitment, the estimate for the direct effect of HRMPs was 0.14 ( $p<0.10$ ), and the standardized indirect effect, mediated by OV, was 0.37 (p<0.02; 95\% Cl = 0.21 to 0,40 ). In both cases, the confidence intervals for the indirect effect did not include zero (Taylor, MacKinnon, \& Tein, 2008); hence, the results support the full mediation model.

\section{CONCLUSION}

In this study, we discuss the relationship between HRMPs and performance by focusing on the more proximal employee outcomes-organizational citizenship behaviors and affective commitment. We suggest virtuousness as an alternative explanation of the relationship. We propose that HRMPs can enhance both the outcomes because they can be designed to give employees the amount of autonomy required for self-determination, create opportunities for individual development, and allow people to extract more meaning from their jobs, thus linking them to higher collective purposes. Thus, HRMPs can be perceived by members as moral in an Aristotelian sense, becoming signals for employees to perceive moral goodness, human impact, and generalized benefit provided by organizations. Because HRMPs can be seen as good practices and inherently worthy, satisfying the eudaemonic and inherent value (Cameron \& Winn, 2012), they strengthen OV. Similar to other organizational level attributes and due to its inherently worthy content of optimism, trust, compassion, integrity, and forgiveness, OV prescribes appropriate ways of thinking, feeling, and acting: an affective connection between individuals and organizations and a proclivity to act in favor of organizations. 







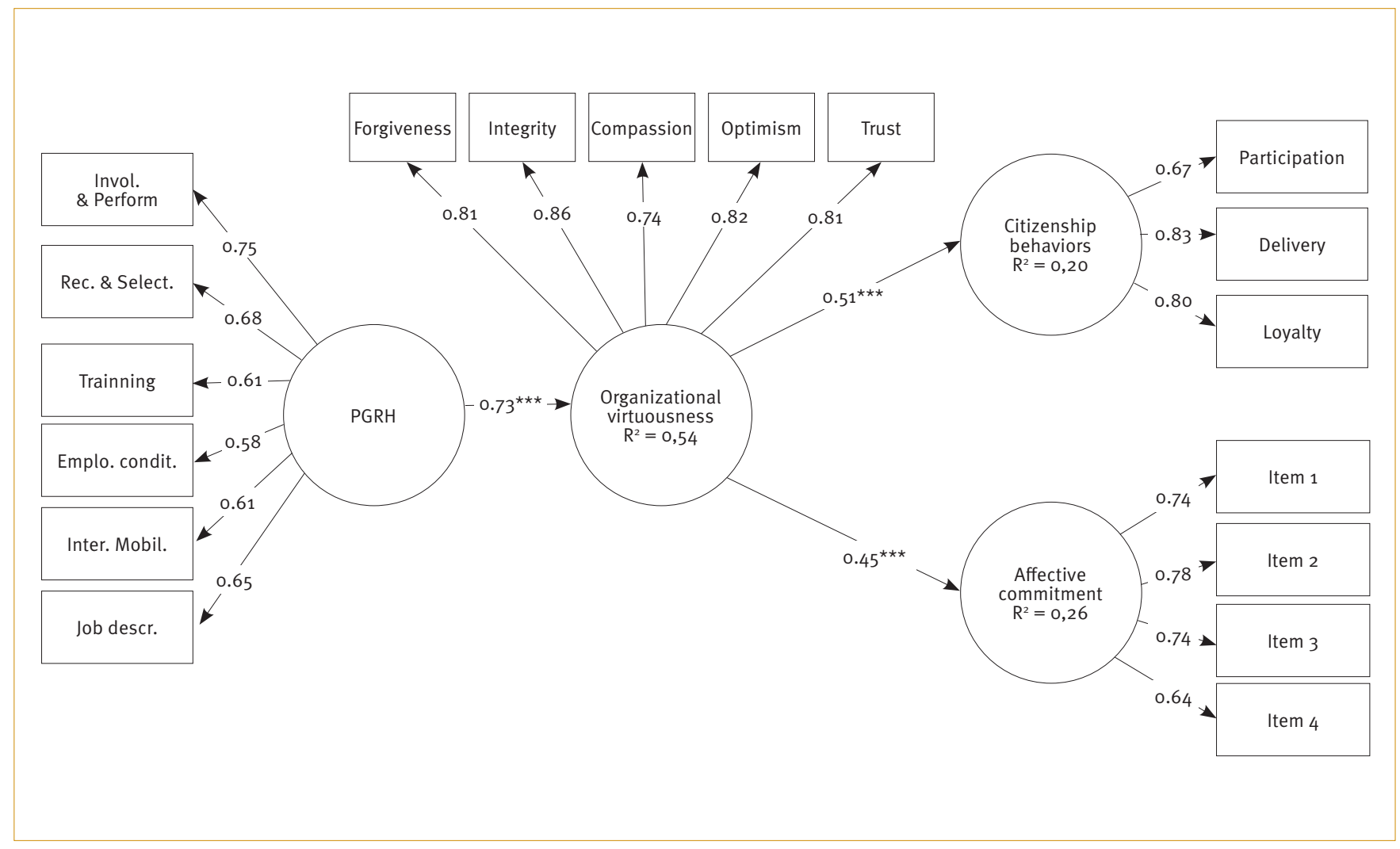

Note: All path values between observed and latent variables are significant at p<0.001

The results support the general framework wherein OV fully mediates the relationship between HRMPs and employee attitudes and behaviors. Members who perceive their work context as promoting optimism, trust, compassion, integrity, and forgiveness show higher levels of citizenship behaviors and affective commitment. Describing HRMPs in use in their contexts as promoting participation and performance, careful recruitment and selection, training opportunities, good employment conditions, internal mobility opportunities, and carefully designed jobs, practices that fall into the moral/ethic nature of the humanistic management trend (Spitzeck, 2011; Arnaud \& Wasieleski, 2014) leads employees to infer that a virtuous character exists in organizations. Higher levels of OV engender positive emotions and willingness to act positively toward the organization, operationalized as affective commitment and citizenship behaviors. Although this effect was not studied, these emotions and behaviors as a collective pattern, can reinforce the OV level (Cameron \& Winn, 2012).

Our study proposes a distinct alternative path for the relationship between HRMPs and employee outcomes, contributing to knowledge on the causal chain linking HRMPs to organizational outcomes. Inconsistencies in the literature on relationships between HRMPs and employee outcomes (Yu, Ahmad, \& Yap 2012; Bal et al., 2013), can be interpreted as a lack of explanatory power of the social exchange theory and its associated constructs, such as support or justice (Cropanzano \& Mitchel, 2005). Instead of describing psychological states resulting from a roughly balanced exchange relationship between individuals and organizations, as an organizational level attribute, $\mathrm{OV}$ and its content becomes a fundamental part of employees' context facilitating their understanding of the behaviors required and supported and the appropriate ways of thinking, feeling, and acting. Well- designed HRMPs and corresponding high levels of OV underscore altruistic motives, promote intrinsic or integrated regulation, and help extract a richer meaning from the jobs employees perform. Thus, HRMPs influence organizational citizenship behavior and affective commitment by creating OV.

Further, we linked HMRP literature to the OV approach. Although virtuousness is defined as a fundamentally positive human organizational attribute (Cameron \& Winn, 2012; Cameron 
et al., 2011), research is still lacking on OV's antecedents. Most authors exploring this construct are more interested in its consequents at the individual or organizational level. The limited research on virtuousness' antecedents focuses on authentic (Rego, Reis, \& Pina e Cunha, 2015) or servant (Searle \& Barbuto, 2011) leadership, which is foreseeable due to OV's cultural nature. We expand this literature by highlighting the HRMP's role and proposing that OV is created and nurtured by well-designed HRMPs that stimulate self-determination (Decy \& Ryan, 2008), stewardship (Hernandez, 2012), and human dignity and virtue (Melé, 2003; Spitzeck, 2011). Moreover, contrary to Guerci et al. (2015), who suggest that to have a positive impact on ethical climate, HRMPs should encompass ethical elements, we propose that HRMPs can inherently embrace moral goodness, human impact, and generalized benefit for individuals generating OV. Thus, we join earlier proposals about the potential ethical nature of high involvement work practices (Guest, 2007; Legge, 1998; Boxall \& Purcell, 2007).

By locating OV in the causal chain linking HRMPs and organizational performance, as a mediator of the relationship between HRMPs and organizational citizenship behaviors and affective commitment, this study provides an enriched view on improving individual and organizational performance. Further, we show that HRMPs need to nurture OV to promote these two important employee outcomes. Thus, human resource managers can design HRMPs with OV in mind, and line managers can work with their subordinates emphasizing the moral nature of practices and the virtuous aspects of their work contexts.

Despite these contributions, this study has limitations. First, despite the procedures used to control for common method variance, the value of some relationships can be inflated. Further, data coming from just one organization are important to control for external factors that can affect the pattern of relationships encountered, but limit the scope of our conclusions for that organization. Future research could address these issues and focus on organizations wherein virtuousness seems to play a more relevant role, such as public and non-profit organizations or the health care sector. However, future research could directly contrast the explanatory power of OV versus social exchange theories variables. Additionally, in service settings such as the one here, service climate (Hong, Liao, Hu, \& Jiang, 2013; Bowen \& Schneider, 2014) is the best established mediator for the relationship between HRMPs practices and customer experiences leading to organizational level performance by activating individual level outcomes, whose explanatory power could be confronted with virtuousness. In both cases, focusing on the organizational level seems appropriate in future research.

\section{REFERENCES}

Ahmad, S., \& Schroeder, R. G. (2003). The impact of human resource management practices on operational performance: Recognizing country and industry differences. Journal of Operations Management, 21(1), 19-43. doi:10.1016/S0272-6963(02)00056-6

Arnaud, S., \& Wasieleski, D. M. (2014). Corporate humanistic responsibility: Social performance through managerial discretion of the HRM. Journal of Business Ethics, 120(3), 313-334. doi:10.1007/s10551-013-1652-z

Bal, P. M., Kooij, D. T. A. M., \& De Jong, S. B. (2013). How do developmental and accommodative HRM enhance employee engagement and commitment? The role of psychological contract and SOC strategies. Journal of Management Studies, 50(4), 545-572. doi:10.1111/joms.12028

Becker, B. E., Huselid, M. A., Pickus, P. S., \& Spratt, M. F. (1997). HR as a source of shareholder value: Research and recommendations. Human resource management, 36(1), 39-47. doi:10.1002/(SICl)1099050X(199721)36:1く39::AID-HRM8>3.0.CO;2-X

Bell, S. J., \& Menguc, B. (2002). The employee-organization relationship, organizational citizenship behaviors, and superior service quality. Journal of Retailing, 78(2), 131-146. doi:10.1016/So022-4359(02)00069-6

Berg, J. M., Dutton, J. E., \& Wrzesniewski, A. (2013). Job crafting and meaningful work. In B. J. Dik, Z, S. Byrne, \& M. Steger (Eds.), Purpose and meaning in the workplace. Washington, DC: American Psychological Association

Bernacchio, C., \& Couch, R. (2015). The virtue of participatory governance: A Maclntyrean alternative to shareholder maximization Business Ethics: A European Review, 24(S2), S130-S143. doi:10.1111/ beer.12101

Bettencourt, L. A., Gwinner, K. P., \& Meuter, M. L. (2001). A comparison of attitude, personality, and knowledge predictions of service-oriented organizational citizenship behaviors. Journal of Applied Psychology, 86(1), 29-41.

Bowen, D., \& Schneider, B. (2014). A service climate synthesis and future research agenda. Journal of Service Research, 17(1), 5-22. doi:10.1177/1094670513491633

Boxall, P., \& Purcell, J. (2007). Strategic management and human resources: the pursuit of productivity, flexibility, and legitimacy. In A. Pinnington, R. Macklin, T. Campbell (Eds.), Human Resource Management - Ethics and Employment (pp. 66-80). Oxford, New York: Oxford University Press.

Bright, D. S., Cameron, K. S., \& Caza, A. (2006). The amplifying and buffering effects of virtuousness in downsized organizations. Journal of Business Ethics, 64(3), 249-269. doi:10.1007/s10551-005-5904-4

Bright, D. S., Winn, B. A., \& Kanov, J. (2014). Reconsidering virtue: Differences of perspective in virtue ethics and the positive social sciences. Journal of Business Ethics, 119(4), 445-460. doi:10.1007/ S10551-013-1832-X

Cameron, K., Dutton, J. E., Quinn, R. (Eds.). (2003). Positive organizational scholarship - foundations of a new discipline. San Francisco: Berret-Koehler Publishers Inc.

Cameron, K., Bright, D., \& Caza, A. (2004). Exploring the relationships between Organizational Virtuousness and performance. American BehavioralScientist,47(6),766-790.doi:10.1177/0002764203260209 
Cameron, K., Mora, C., Leutscher, T., \& Calarco, M. (2011). Effects of positive practices on organizational effectiveness. The Journal of Applied Behavioral Science, 47(3), 266-308. doi:10.1177/0021886310395514

Cameron, K. S., \& Winn, B. (2012). Virtuousness in organizations. In K. S. Cameron \& G. M. Spreitzer (Eds.), Handbook of positive organizational scholarship (pp. 231-243). New York, NY: Oxford University Press.

Chatman, J., A., \& O’Reilly, C. A. (2016). Paradigm lost: Reinvigorating the study of organizational culture. Research in Organizational Behavior, 36, 199-224. doi:10.1016/j.riob.2016.11.004

Cheung, G. W., \& Lau, R. S. (2008). Testing mediation and suppression effects of latent variables: Bootstrapping with structural equation models. Organizational Research Methods, 11(2), 296-325. doi:10.1177/1094428107300343

Chuang, C. H., \& Liao, H. (2010). Strategic human resource management in service context: Taking care of business by taking care of employees and customers. Personnel Psychology, 63(1), 153-196. doi:10.1111/j.1744-6570.2009.01165.x

Combs J., Liu, Y., Hall, A., \& Ketchen, D. (2006). How much do highperformance work practices matter? A meta-analysis of their effects on organizational performance. Personnel Psychology, 59(3), 501528. doi:10.1111/j.1744-6570.2006.00045.x

Cropanzano, R., \& Mitchel, M. (2005). Social exchange theory: An interdisciplinary review. Journal of Management, 31(6), 874-900. doi:10.1177/0149206305279602

Deci, E. L., \& Ryan, R. M. (2008). Self-determination theory: A macrotheory of human motivation, development, and health. Canadian psychology/Psychologie canadienne, 49(3), 182-185. doi:10.1037/a0012801

Dyer, L., \& Reeves, T. (1995). Human resource strategies and firm performance: What do we know and where do we need to go? The International Journal of Human Resource Management, 6(3), 656670. doi:10.1080/09585199500000041

Ehrhart, M. G., Schneider, B., \& Macey, W. H. (2014). Organizational climate and culture: An introduction to theory, research, and practice. New York, NY: Routledge.

Fabi, B., Lacoursière, R., \& Raymond, L. (2015). Impact of highperformance work systems on job satisfaction, organizational commitment, and intention to quit in Canadian organizations. International Journal of Manpower, 36(5), 772-790. doi:10.1108/IJM01-2014-0005

Fabi, B., Lacoursière, R., \& Raymond, L. (2015). Impact of highperformance work systems on job satisfaction, organizational commitment, and intention to quit in Canadian organizations. International Journal of Manpower, 36(5), 772-790. doi:10.1108/IJM01-2014-0005

Gavin, J., \& Mason, R. (2004). The virtuous organization: The value of happiness in the workplace. Organizational Dynamics, 33(4), 379392. doi:10.1016/j.orgdyn.2004.09.005

Gong, Y., Law, K., Chang, S., \& Xin, K., (2009). Human resource management and firm performance: The differential role of managerial affective and continuance commitment. Journal of Applied Psychology, 94(1), 263-275. doi:10.1037/ao013116

Gratton, L., \& Truss, C. (2003). The three-dimensional people strategy: Putting human resources policies into action. The Academy of Management Executive, 17(3), 74-86.
Guerci, M., Radaelli, G., Siletti, E., Cirella, S., \& Shani, A. R. (2015). The impact of human resource management practices and corporate sustainability on organizational ethical climates: An employee perspective. Journal of Business Ethics, 126(2), 325-342. doi:10.1007/ S10551-013-1946-1

Guest, D. (1997). Human resource management and performance: A review and research agenda. The International Journal of Human Resource Management, 8(3), 263-276. doi:10.1080/095851997341630

Guest, D. (2007), HRM and performance: Can partnership address the ethical dilemmas? In A. Pinnington, R. Macklin, \& T. Campbell (Eds.), Human Resource Management - Ethics and Employment (pp. 52-65). Oxford, NY: Oxford University Press.

Harman, H. H. (1967). Modem factor analysis. Chicago: University of Chicago Press.

Heffernan, M., \& Dundon, T. (2012). Researching employee reactions to high performance work systems in the service sector: the role of organizational justice theory. 16th ILERA (IIRA) World Congress, Philadelphia, USA.

Hernandez, M. (2008). Promoting stewardship behavior in organizations: A leadership model. Journal of Business Ethics, 80(1), 121-128. doi:10.1007/s10551-007-9440-2

Hernandez, M. (2012). Toward an understanding of the psychology of stewardship. Academy of Management Review, 37(2), 172-193. doi:10.5465/amr.2010.0363

Hong, Y., Liao, H., Hu, J., \& Jiang, K. (2013). Missing link in the service profit chain: A meta-analytic review of the antecedents, consequents, and moderators of service climate. Journal of Applied Psychology, 98(2), 237-267.

Jiang, K., Lepak, D., Hu, J., \& Baer, J. (2012). How does human resource management influence organizational outcomes? A meta-analytic investigation of mediating mechanisms. Academy of Management Journal, 55(6), 1264-1294. doi:10.5465/amj.2011.0088

Kehoe, R.R., \& Wright, P.M. (2013). The impactofhigh-performance human resource practices on employees' attitudes and behaviors. Journal of Management, 39(2), 366-391. doi:10.1177/0149206310365901

Koys, D. (2001). The effects of employee satisfaction, organizational citizenship behavior, and turnover on organizational effectiveness: A unit-level, longitudinal study. Personnel Psychology, 54(1), 101-114. doi:10.1111/j.1744-6570.2001.tbooo87.x

Kuvaas, B. (2008). An exploration of how the employee-organization relationship affects the linkage between perception of developmental human resource practices and employee outcomes. Journal of Management Studies, 45(1), 1-25. doi:10.1111/j.1467-6486.2007.00710.x

Lamba, S., \& Choudhary, N. (2013). Impact of HRM practices on organizational commitment of employees. International Journal of Advancements in Research \& Technology, 2(4), 407-423.

Legge, K. (1998). Is HRM ethical? Can HRM be ethical? In M. Parker (Ed.), Ethics \& Organizations. London, UK: Sage Publications.

Lepak, D., Liao, H., Chung, Y., \& Harden, E. (2006). A conceptual review of human resource management systems in strategic human resource management research. In J. J. Martocchio (Ed.), Research in Personnel and Human Resources Management (pp. 217-271). Bingley, UK: Emerald Group Publishing Limited

Mathieu, J. E., \& Zajac, D. (1990). A review and meta-analysis of the antecedents, correlates, and consequences of organizational commitment. Psychological Bulletin, 108(2), 171-194. doi:10.1037/0033-2909.108.2.171 
Mathieu, J. E., \& Zajac, D. (1990). A review and meta-analysis of the antecedents, correlates, and consequences of organizational commitment. Psychological Bulletin, 108(2), 171-194. doi:10.1037/00332909.108.2.171

McElroy, J. (2001). Managing workplace commitment by putting people first. Human Resource Management Review, 11(3), 327-335. doi:10.1016/S1053-4822(00)00054-1

Melé, D. (2003). The challenge of humanistic management. Journal of Business Ethics, 44(1), 77-88.

Meyer, J. P., \& Allen, N. (1991). A three-component conceptualization of organizational commitment. Human Resource Management Review, 1(1), 61-89. doi:10.1016/1053-4822(91)90011-Z

Meyer, J. P., \& Allen, N. J. (1997). Commitment in the workplace: Theory, research, and application. Thousand Oaks, CA: Sage Publications.

Meyer, J. P., \& Smith, C. A. (2000). HRM practices and organizational commitment: Test of a mediation model. Canadian Journal of Administrative Sciences/Revue canadienne des sciences de l'administration, 17(4), 319-331. doi:10.1111/j.1936-4490.2000.tboo231.x

Morrison, E. W. (1996). Organizational citizenship behavior as a critical link between HRM practices and service quality. Human Resource Management, 35(4), 493-512. doi:10.1002/(SICI)1099050X(199624)35:4‘493::AID-HRM4'3.0.CO;2-R

Nascimento, J., Lopes, A., \& Salgueiro, F. (2008). Estudo sobre a validação de "Modelo de Comprometimento Organizacional" de Meyer e Allen para o contexto português. Comportamento Organizacional e Gestão, 14(1), 115-133.

Newman, A., Miao, Q., Hofman, P. S., \& Zhu, C. J. (2016). The impact of socially responsible human resource management on employees' organizational citizenship behaviour: The mediating role of organizational identification. The International Journal of Human Resource Management, 27(4), 440-455. doi:10.1080/09585192.2015.1042895

Park, N., \& Peterson, C. (2003). Virtues and organizations. In K. Cameron, J. Dutton, \& R. Quinn (Eds.), Positive Organizational Scholarship - Foundations of a New Discipline (pp. 33-47). San Francisco, CA: Berret-Koehler Publishers Inc.

Podsakoff, P. M., MacKenzie, S. B., Paine, J. B., \& Bachrach, D. G. (2000). Organizational citizenship behaviors: A critical review of the theoretical and empirical literature and suggestions for future research. Journal of management, 26(3), 513-563. doi:10.1177/014920630002600307

Podsakoff, P., MacKenzie, S., Lee, J. \& Podsakoff, N. (2003). Common method biases in behavioral research: A critical review of the literature and recommended remedies. Journal of Applied Psychology, 88(5), 879-903. doi:10.1037/0021-9010.88.5.879

Rego, A., Reis, D., \& Pina e Cunha, M. (2015). Authentic leaders promoting store performance: The mediating roles of virtuousness and potency. Journal of Business Ethics, 128(3), 617-634. doi:10.1007/ S10551-014-2125-8

Rego, A., Ribeiro, N., \& Pina e Cunha, M. (2010). Perceptions of organizational virtuousness and happiness as predictors of organizational citizenship behaviors. Journal of Business Ethics, 93(2), 215-235. doi:10.1007/s10551-009-0197-7

Ribeiro, N., \& Rego, A. (2009). Does perceived organizational virtuousness explain organizational citizenship behaviors? International Journal of Psychological and Behavioral Sciences, 3(6), 1103-1110.
Schein, E. H. (2010). Organizational culture and leadership (4th ed.). San Francisco, CA: Jossey Bass.

Schneider B., Ehrhart, M. G., Mayer D. M., Saltz J. L., \& Niles-Jolly K. (2005). Understanding organization-customer links in service settings. Academy of Management Journal, 48(6), 1017-1032. doi:10.5465/amj.2005.19573107

Schneider, B., González-Romá, G., Ostroff, C., \& West, M. A. (2017). Organizational climate and culture: Reflections on the history of the constructs in the Journal of Applied Psychology. Journal of Applied Psychology, 102(3), 468-482. doi:10.1037/aplooooogo

Searle, T., \& Barbuto, J. (2011). Servant leadership, hope, and organizational virtuousness: A framework exploring positive micro and macro behaviors and performance impact. Journal of Leadership \& Organizational Studies, 18(1), 107-117. doi:10.1177/1548051810383863

Sison, A. J., \& Ferrero, I. (2015). How different is neo-Aristotelian virtue from positive organizational virtuousness? Business Ethics: A European Review, 24(S2), S78-S98. doi:10.1111/beer.12099

Spitzeck, H. (2011). An integrated model of humanistic management. Journal of Business Ethics, 99(1), 51-62.

Staw, B. M., \& Barsade, S. G. (1993). Affect and managerial performance: A test of the sadder-but-wiser versus happier-and-smarter hypotheses. Administrative Science Quarterly, 38(2), 304-331. doi:10.2307/2393415

Sun, L-Y, Aryee, S., \& Law, K. (2007). High-performance human resource practices, citizenship behavior, and organizational performance: A relational perspective. Academy of Management Journal, 50(3), 558-577. doi:10.2307/20159873

Takeuchi, R., Chen, G., \& Lepak, D., (2009). Through the looking glass of a social system: Cross-level effects of high-performance work systems on employees' attitudes. Personnel Psychology, 62(1), 1-29. doi:10.1111/ j.1744-6570.2008.01127.x

Takeuchi, R., Lepak, D. P., Wang, H., \& Takeuchi, K. (2007). An empirical examination of the mechanisms mediating between high-performance work systems and the performance of Japanese organizations. Journal of Applied Psychology, 92(4),1069-1083. doi:10.1037/0021 9010.92.4.1069

Taylor A. B., MacKinnon D. P., \& Tein J. Y. (2008). Tests of the three-path mediated effect. Organizational Research Methods, 11(2), 241-269. doi:10.1177/1094428107300344

Tsui, A. S., Pearce, J. L., Porter, L. W., \& Tripoli, A. M. (1997). Alternative approaches to the employee-organization relationship: Does investment in employees pay off? Academy of Management journal, 40(5), 10891121. doi:10.2307/256928

Tsui, A. S., Pearce, J. L., Porter, L. W., \& Tripoli, A. M. (1997). Alternative approaches to the employee-organization relationship: Does investment in employees pay off? Academy of Management journal, 40(5), 10891121. doi: $10.2307 / 256928$

Yagil, D. (2014). Service quality. In B. Schneider \& K. Barbera (Eds.), The Oxford Handbook of Organizational Climate and Culture. New York, NY: Oxford University Press.

Weaver, G. R., \& Treviño, L. K. (2001). The role of human resources in ethics/compliance management: A fairness perspective. Human Resource Management Review, 11(1-2), 113-134. doi:10.1016/S10534822(00)00043-7 
Whitener, E. (2001). Do "high commitment" human resource practices affect employee commitment? A cross-level analysis using hierarchical linear modeling. Journal of Management, 27(5), 515-535. doi:10.1016/ So149-2063(01)00106-4

Wright, P. M., Gardner, T. M., \& Moynihan, L M. (2003). The impact of HR practices on the performance of business units. Human Resource Management Journal, 13(3), 21-36. doi:10.1111/j.1748-8583.2003.tbooo96.x
Yu, W. G., Ahmad, K. Z., \& Yap, S. F. (2012). Promoting organizational citizenship behaviour through high involvement human resource practices: An attempt to reduce turnover intention. GSTF Journal of Law and Social Sciences (JSS), 1(1), 163-168

Zacharatos, A., Barling, J., \& Iverson, R. (2005). High-performance work systems and occupational safety. Journal of Applied Psychology, 9o(1), 77-93. doi:10.1037/0021-9010.90.1.77 